\section{Tackling Informal Entrepreneurship in Latin America: A Critical Evaluation of the Neo-Liberal Policy Approach}

\author{
Colin C. Williams ${ }^{1}$ and Youssef Youssef ${ }^{2^{*}}$ \\ ${ }^{1}$ Management School, University of Sheffield, Sheffield, UK \\ ${ }^{2}$ Business School, Humber Institute of Technology and Applied Learning, Toronto, Canada
}

"Corresponding author: Youssef Youssef, Humber Institute of Technology and Applied Learning, H215/ 3199, Lake Shore Boulevard West, Toronto, Ontario, M8V 1K8, Canada, Tel: 44-114-222-3476; E-mail: youssef.youssef@humber.ca

Rec date: May 12, 2014, Acc date: May 26, 2014, Pub date: June 06, 2014

Copyright: (c) 2014 Williams et al. This is an open-access article distributed under the terms of the Creative Commons Attribution License, which permits unrestricted use, distribution, and reproduction in any medium, provided the original author and source are credited.

\begin{abstract}
Since the turn of the millennium, there has been widespread recognition that a sizeable and growing share of the global workforce is in the informal sector. To explain this, neo-liberals contend that enterprises operate in the informal sector due to high taxes, public sector corruption and too much state interference in the free market and that the consequent remedy is to reduce taxes, public sector corruption and the regulatory burden via minimal state intervention. This paper evaluates critically this neo-liberal policy approach. To do this, International Labor Organization data from 16 Latin American countries on the share of the workforce in informal sector enterprises is compared with cross-national variations in tax rates, corruption and levels of state interference using World Bank development indicators. Revealing that one in three non-agricultural workers in Latin America are employed in informal sector enterprises and analyzing the economic and social conditions in different countries, no support is found for the neo-liberal tenets that higher tax rates, greater levels of corruption and state interference are correlated with larger informal sectors. Instead, higher levels of regulation and state intervention are associated with smaller (not larger) informal economies resulting in a tentative call for more, rather than less, regulation of the economy and state intervention to protect workers.
\end{abstract}

Keywords: Informal economy; Informal entrepreneurship; Development economics; Economic development; Developing countries; Latin America

\section{Introduction}

Since the turn of the millennium, there has been growing recognition that enterprises operating in the informal sector are not a minor residue leftover from a pre-modern mode of production [1,2]. They are an extensive, persistent and even growing feature of the global economic landscape, with some one-third of the global nonagricultural workforce having their main job in such informal sector enterprises [3]. To explain the pervasiveness and expansion of informal sector enterprise, neo-liberals have contended that enterprises operate in the informal sector due to high taxes, public sector corruption and too much state interference in the free market. The outcome is a call for reductions in taxation and corruption along with de-regulation in order to minimize state interference in the market [4-8]. The aim of this paper is to evaluate critically the validity of this neo-liberal policy approach.

To commence, the first section will briefly define informal sector enterprise and review the neo-liberal explanation for the prevalence of such enterprise along with its consequent policy approach for tackling enterprise in the informal sector. To evaluate critically the validity of various tenets of this neo-liberal approach, the second section introduces the methodology used. This explores whether a correlation exists between the cross-national variations in the prevalence of informal sector enterprise and cross-national variations in tax rates, corruption and state interference in the market. To do this, International Labor Office data on employment in informal sector enterprises in 16 Latin American countries are compared with various World Bank development indicators on tax rates, corruption and state intervention. The third section reports the findings on the crossnational variations in the share of the non-agricultural workforce employed in informal sector enterprises whilst the fourth section provides a preliminary analysis of the validity of the various tenets of the neo-liberal perspective. The fifth and final section draws some conclusions regarding the validity of the neo-liberal approach towards tackling informal sector enterprise and tentatively calls for greater rather than less regulation of the economy and state intervention to protect workers.

In this paper, the definition of informal sector enterprise is that adopted by the 15th International Conference of Labor Statisticians (ICLS) in 1993 [9-11]. This defines enterprises in the informal sector as private unincorporated enterprises that are unregistered or small in terms of the number of employed persons" [11]. Informal sector enterprises are thus either "small" or "unregistered" enterprises that are "unincorporated", by which is meant that they are not constituted as a separate legal entity independent of the individual (or group of individuals) who owns it, and for which no complete set of accounts is kept. By "unregistered" is meant they are not registered under specific forms of national legislation (e.g., factories' or commercial acts, tax or social security laws, professional groups' regulatory acts). Holding a trade license or business permit under local regulations does not qualify as registration. An enterprise is "small", moreover, when its size in terms of employment levels is below a specific threshold (e.g., five employees) determined according to national circumstances [9-11]. Throughout this paper, informal sector enterprises are defined as unregistered or small private enterprises that are unincorporated as 
Page 2 of 9

separate legal entities and do not keep a complete set of accounts for tax and social security purposes.

\section{Explaining the prevalence of informal sector enterprise: the neo-liberal perspective}

For much of the last century, the recurrent belief was that the modern formal sector was expanding and that the informal sector was a remnant from a pre-modern mode of production that was gradually waning and disappearing $[1,2,12]$. Viewed from this modernization perspective, the prevalence of informal sector enterprises in an economy signals its "backwardness" and "under-development", and there is little reason to pay much attention to these enterprises as they will naturally and inevitably disappear with economic advancement and modernization.

\begin{tabular}{|c|c|c|c|c|c|}
\hline Country & Year & $\begin{array}{l}\% \text { of jobs in informal } \\
\text { sector enterprises }\end{array}$ & $\begin{array}{l}\text { Own-account workers } \\
\text { and employers as \% of } \\
\text { all employed in informal } \\
\text { enterprises }\end{array}$ & $\begin{array}{l}\text { Formal jobs as \% of } \\
\text { jobs in informal } \\
\text { enterprises }\end{array}$ & Type of economy \\
\hline Honduras & 2009 & 58.3 & 62.8 & 2.4 & Semi-informal \\
\hline Nicaragua & 2009 & 54.4 & 61 & 6.8 & Semi-informal \\
\hline El Salvador & 2009 & 53.4 & 62.7 & 3.4 & Semi-informal \\
\hline Colombia & 2010 & 52.2 & 72.6 & 3.4 & Semi-informal \\
\hline Bolivia & 2006 & 52.1 & 62.2 & 1 & Semi-informal \\
\hline Peru & 2009 & 49 & 71 & 1.6 & Semi-formal \\
\hline Paraguay & 2009 & 37.9 & 62.8 & 0 & Mostly formal \\
\hline Ecuador & 2009 & 37.3 & 60.9 & 1.1 & Mostly formal \\
\hline Costa Rica & 2009 & 37 & 63 & 11.9 & Mostly formal \\
\hline Venezuela & 2009 & 36.3 & 84.3 & 1.7 & Mostly formal \\
\hline Mexico & 2009 & 34.1 & 56 & 1.8 & Mostly formal \\
\hline Uruguay & 2009 & 33.9 & 70.5 & 11.5 & Mostly formal \\
\hline Argentina & 2009 & 32.1 & 68.2 & 1 & Mostly formal \\
\hline Dominican rep & 2009 & 29.4 & 89.1 & 1 & Largely formal \\
\hline Panama & 2009 & 27.7 & 90.6 & 0.7 & Largely formal \\
\hline Brazil & 2009 & 24.3 & 71.2 & 0.4 & Largely formal \\
\hline
\end{tabular}

Table 1: \% of non-agricultural jobs in informal enterprises in Latin American countries.

Source: derived from ILO (2012)

Since the turn of the millennium, this traditional modernization perspective has come under heavy criticism due to the recognition that the informal sector is extensive, persistent and even growing relative to the formal sector in many global regions [10,11,13-19]. Indeed, given that the informal sector worldwide has been estimated to be equivalent to 33 per cent of global GDP (Schneider, 2011) and that 60 per cent of all global jobs are in informal sector enterprises [15], it can no longer be depicted as some residue, relic or remnant from a pre-modern era. The outcome is that new explanations for its prevalence and persistence have emerged.

At first, it was a political economy perspective that replaced the conventional modernization thesis. This viewed enterprises in the informal sector not as prior to or separate from, but as an integral component of, modern-day capitalism, providing businesses with a channel to attain flexible production, profit and cost reduction. Consequently, informal sector enterprises were viewed as a central facet of the new downsizing, sub-contracting and outsourcing arrangements emerging under de-regulated global capitalism, as well as a source of livelihood to which marginalized populations turn in the absence of alternatives [20-25]. Seen in this manner, employment in the informal sector was depicted as resulting from a lack of state intervention in work and welfare to protect workers and as composed almost entirely of "sweatshop-like" dependent employment and/or "false" self-employment conducted by workers as a survival practice out of necessity [26-28].

Over the last decade or so nevertheless, there has been recognition that the majority of work in the informal sector is undertaken on a self-employed basis, often as a matter of choice rather than due to a lack of choice [5,16,29-43]. Grounded in this recognition, a neo-liberal explanation has emerged that reads enterprise in the informal sector to be a direct by-product of over-regulation rather than under-regulation $[4-8,33]$. The level of employment in informal sector enterprises is a direct product of high taxes, a corrupt state system and too much interference in the free market. This leads entrepreneurs and enterprises to make a rational economic decision to voluntarily exit the formal economy in order to avoid the time, costs and effort of operating on a formal basis e.g., [4-8,33,44]. For neo-liberals, operating in the informal sector is a rational economic response 
pursued by entrepreneurs stifled by high taxes, a corrupt public sector and state-imposed institutional constraints [5,6,33,45]. Informal workers are represented as voluntarily operating in the informal sector and heroes throwing off the shackles of state over-regulation e.g., $[5,44]$.

\begin{tabular}{|llllllllll}
\hline $\begin{array}{l}\text { Nearly } \\
\text { formal }\end{array}$ & $\begin{array}{l}\text { Dominantly } \\
\text { formal }\end{array}$ & $\begin{array}{l}\text { Largely } \\
\text { formal }\end{array}$ & $\begin{array}{l}\text { Mostly } \\
\text { formal }\end{array}$ & $\begin{array}{l}\text { Semi- } \\
\text { formal }\end{array}$ & $\begin{array}{l}\text { Semi- } \\
\text { informal }\end{array}$ & $\begin{array}{l}\text { Mostly } \\
\text { informal }\end{array}$ & $\begin{array}{l}\text { Largely } \\
\text { informal }\end{array}$ & $\begin{array}{l}\text { Domin } \\
\text { antly } \\
\text { informal }\end{array}$ & $\begin{array}{l}\text { Nearly } \\
\text { informal }\end{array}$ \\
0 & 10 & 20 & 30 & 40 & 50 & 60 & 70 & 80 & 90 \\
Figure 1: Types of economy: by level of employment in informal sector enterprises.
\end{tabular}

From this neo-liberal perspective in consequence, the level of employment in informal sector enterprises will be greater in economies with higher taxes, public sector corruption and greater state interference and the resultant remedy is to reduce taxes, tackle public sector corruption, deregulation and minimal state intervention. As Nwabuzor [8] asserts, "Informality is a response to burdensome controls, and an attempt to circumvent them", or as Becker [4] puts it, "informal work arrangements are a rational response by micro- entrepreneurs to over-regulation by government bureaucracies". Informal workers are only breaking unfair rules and regulations imposed by excessively intrusive and burdensome governments. The informal sector in consequence is a form of popular resistance to public sector corruption and state over-regulation and informal workers viewed as a political movement that can generate both true democracy and a rational competitive market economy [4].

\section{Relationship between jobs in informal enterprise and corruption}

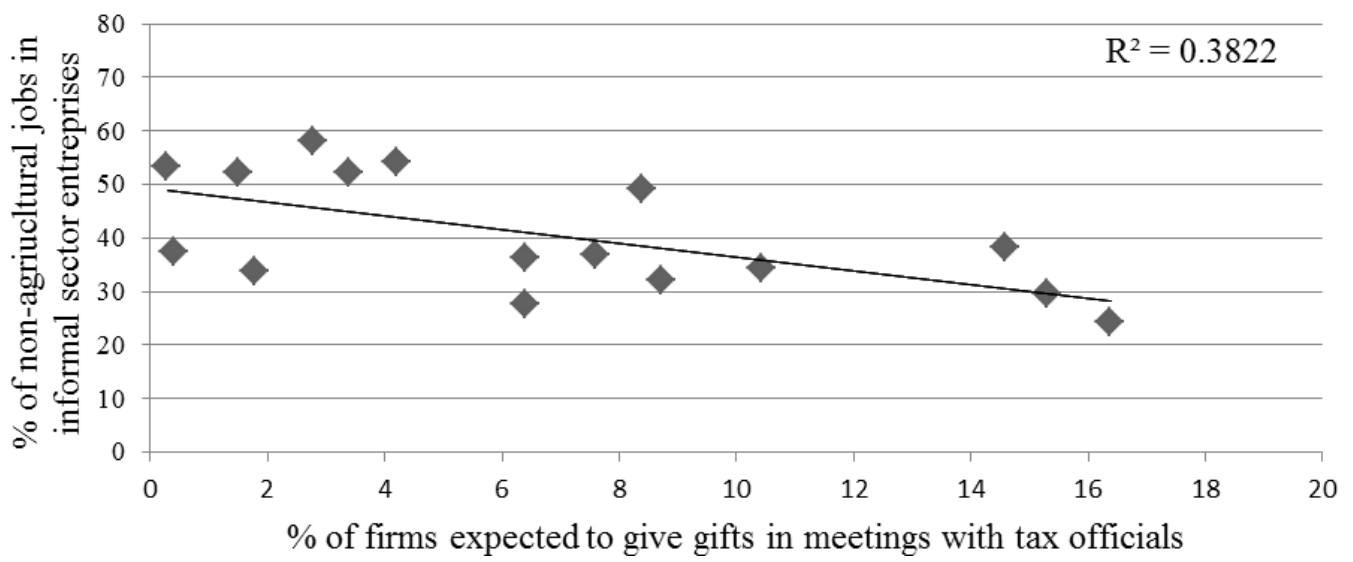

Figure 2: Relationship between jobs in informal enterprise and corruption

However, even if neo-liberals celebrate enterprises operating in the informal sector, it is not their intention to promote them. Rather, their desire is to eradicate informal enterprises as much as the political economists. For neo-liberals, nevertheless, this is achieved by reducing taxes, public sector corruption and state regulations in order to free the formal sector from the constraints that force up labor costs, prevent flexibility and act as a disincentive to those seeking formal jobs. By reducing the regulatory burden and state interference in work and welfare provision, the intention is that the distinction between the formal and informal sectors will disappear because all endeavors will be undertaken in the manner now called "informal", although such activity will be "formal" since it will not be breaking any rules.

The neo-liberal project, in consequence, is to reduce taxes, tackle corruption, de-regulate and give the market free reign by preventing state interference and reducing state welfare provision. Neo-liberals represent the welfare state and the economy as adversaries with one usually viewed as the cause of problems in the other. The difference is that whilst political economists support the welfare state and depict free market capitalism as preventing social equality, neo-liberals support the free market and oppose any intervention that constrains it. Political economists represent state intervention in the economy and social protection as necessary for efficiency and growth. Neo-liberals, in contrast, depict state interference in the economy and welfare provision as interfering with the ability of the market to optimize the efficient allocation of scarce resources. Although there are debates within neo-liberalism regarding the degree to which social protection might be provided [19], neo-liberal commentators are largely negative about social protection due to its negative effects on economic performance. Instead, competitive self-regulatory markets are viewed as superior allocation mechanisms and government interference in such allocation processes (aside from marginal cases of imperfections, externalities or market failure) risks generating crowding-out effects, 
mal-distribution and inefficiency resulting in economies producing less aggregate wealth than if a laissez-faire approach were adopted $[46,47]$.

For neo-liberals, in sum, the persistence and growth of employment in informal sector enterprises is a direct result of high taxes, corruption and state interference in the free market. To evaluate critically the validity of this neo-liberal explanation, each of its tenets can be tested by evaluating the following hypotheses:

- Neo-liberal taxation hypothesis (H1): the level of employment in informal enterprises will be greater in countries with higher tax rates;

- Neo-liberal corruption hypothesis (H2): the level of employment in informal enterprises will be greater in countries with higher levels of public sector corruption; and

- Neo-liberal de-regulatory hypothesis (H3): the level of employment in informal enterprises will be greater in countries with higher levels of state interference in the workings of the free market.

Here, the intention is to evaluate critically these hypotheses in relation to 16 Latin American countries so as to begin to explore the validity of this neo-liberal perspective.

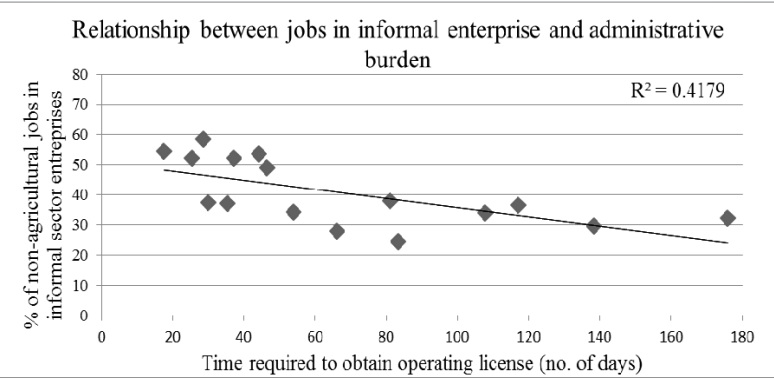

Figure 3: Relationship between jobs in informal enterprise and administrative burden

\section{Methodology}

To evaluate the neo-liberal explanation for the varying level of employment in informal sector enterprise across Latin American countries, firstly, the cross-national variations in the level of employment in the informal sector is evaluated using an International Labor Organization (ILO) dataset. This uses the same common broad definition of employment in informal sector enterprise across all 16 Latin American countries covered and also the same survey methodology. For each country, the Bureau of Statistics of the ILO sends a common questionnaire to all statistical offices of each country requesting the national offices to complete detailed tables on statistics regarding the level of employment in the informal sector and informal employment. To provide this data, either an ILO Department of Statistics questionnaire is used to undertake a survey or information can be used from their national labor force or informal sector surveys already conducted (for further details, see [11]).

In each country, the same ILO definition of employment in informal sector enterprise is used as discussed above, although there are minor variations across countries due to the national variations in what constitutes "small" (e.g., employing less than five employees) and what constitutes an unregistered enterprise due to the different national-level laws applying. In all countries, moreover, persons with more than one job are classified by what they self-report as their main employment and only non-agricultural employment is evaluated (i.e., agriculture, hunting, forestry and fishing is excluded). As such, the data evaluated can be considered sufficiently comparable between countries.

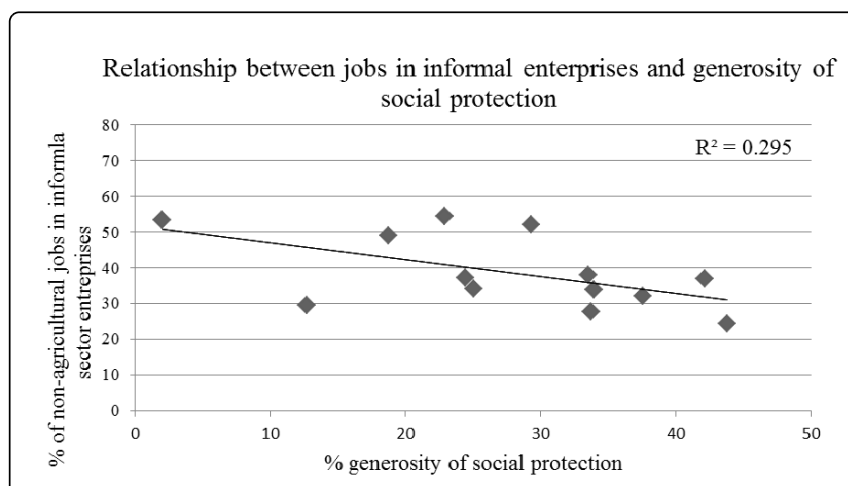

Figure 4: Relationship between jobs in informal enterprises and generosity of social protection

To identify statistical indicators on the broader economic and social conditions that the neo-liberal explanation associates with higher levels of employment in informal sector enterprise, meanwhile, the World Bank development indicators database is here used from which data is reported for the same year in which the survey of the informal sector was conducted in each country [48]. The only indicators from non-official sources are on public sector corruption, which are taken from Transparency International's corruption perceptions index (Transparency International, 2013) and the Inter-Country Risk Guide (ICRG) corruption index (ICRG, 2013) again for the relevant year in each country.

To evaluate the neo-liberal taxation hypothesis (H1), indicators previously used when assessing the validity of this hypothesis in relation to the level of informal employment in Europe $[3,49,50]$ are employed, namely the World Bank [48]country-level indicators on:

- Taxes on goods and services as a percentage of revenue. This covers general sales and turnover or value added taxes, selective excises on goods, selective taxes on services, taxes on the use of goods or property, taxes on extraction and production of minerals and profits of fiscal monopolies;

- Taxes on income, profits and capital gains as a percentage of revenue. This includes taxes on the actual or presumptive net income of individuals, the profits of corporations and enterprises, and capital gains on land, securities and other assets.

- Taxes on revenue (excluding grants) as a percentage of GDP. Revenue includes cash receipts from taxes, social contributions and other revenues (e.g., fines, fees, rent and income from property or sales).

- Tax revenue as a percentage of GDP. Tax revenue covers compulsory transfers to central government for public purposes. Compulsory transfers such as fines, penalties, and most social security contributions are excluded. Refunds and corrections of erroneously collected tax revenue are treated as negative revenue.

- Total tax rate as percentage of commercial profits. This covers the taxes and mandatory contributions payable by businesses after 
allowable deductions and exemptions as a share of commercial profits. Taxes withheld (e.g., personal income tax) or collected and remitted to tax authorities (e.g., value added taxes, sales taxes or goods and service taxes) are excluded.

Meanwhile, the neo-liberal corruption hypothesis (H2) is evaluated using four indicators:

- Transparency International's Corruption Perceptions Index (CPI), which is a composite index of perceptions of public sector corruption from 14 expert opinion surveys. It scores nations on a 0-10 scale, with zero indicating high levels and 10 low levels of perceived public sector corruption (Transparency International, 2013).

- The Inter-Country Risk Guide (ICRG) corruption index (ICRG, 2013);

- The percentage of firms making informal payments to public officials, and

- The percentage of firms expected to give gifts in meetings with tax officials.

To evaluate the neo-liberal de-regulatory hypothesis (H3), finally, the following six World Bank development indicators are used:

- Time required (in days) to obtain an operating license;

- The time spent dealing with officials as a percentage of management time by enterprise owners;

- The time required (in days) to start a business;

- The overall 'ease of doing business' ranking for each country from the World Bank Doing Business Surveys, which is a relative proxy indicator of the regulatory burden in each country;

- Social contributions as a \% of revenue. This includes social security contributions by employees, employers and self-employed individuals, and other contributions whose source cannot be determined, as well as actual or imputed contributions to social insurance schemes operated by governments; and

- The generosity of social protection in each country, namely the percentage of the population receiving social protection which is adequate to have progressive effects on the distribution of wellbeing and help reduce poverty by providing adequate support to beneficiaries.

To compare cross-national variations in the level of employment in informal sector enterprise and the economic and social characteristics each hypothesis asserts are associated, bivariate regression analysis is here undertaken. With the small sample size of just 16 countries and lack of necessary controls, multivariate regression analysis is not possible. To analyze the correlations given the non-parametric nature of the data, Spearman's rank correlation coefficient (rs) is used. Despite this limitation of only using bivariate regression analysis, and as will now be seen, the findings that result are meaningful regarding the validity of the different hypotheses.

\section{Results}

In the 16 Latin American countries for which ILO data is available on the level of employment in informal sector enterprise, the unweight average is that two in five (40.6 per cent) of the non-agricultural workforce have their main job in informal sector enterprises. Given the variable size of the workforce across these economies however, a weighted average figure is needed, which reveals that exactly one-third (33.3 per cent) of the non-agricultural workforce are employed in their main job in informal sector enterprises. Employment in informal sector enterprises is not some minor residue of little importance. As the main occupation of 1 in 3 of the non-agricultural labor force in these Latin American countries, this large sphere employs a significant share of the workforce.

However, this overall figure masks some marked cross-national variations. As Table 1 reports, the proportion of the non-agricultural workforce whose main job is in informal sector enterprises ranges from 58.3 per cent in Honduras and 54.4 per cent in Nicaragua to 27.7 per cent in Panama and 24.3 per cent in Brazil. Indeed, in 5 of the 16 Latin American countries surveyed, over half of the non-agricultural workforce has their main job in informal enterprises (Table 1).

Indeed, those countries where a greater proportion of employment in informal enterprises is composed of employers and own-account workers (e.g., 90.6 per cent in Panama) signal that informal sector entrepreneurs employ relatively few employees. Those countries where employers and own-account workers are a lower share of total employment in informal sector enterprises (e.g., 56 per cent in Mexico) signify that these informal sector entrepreneurs employ a larger number of employees. However, the proportion of the nonagricultural workforce employed in informal sector enterprises is not significantly correlated with either the proportion who is own-account workers and employers, and neither is it correlated with the share that are in formal jobs in informal sector enterprises.

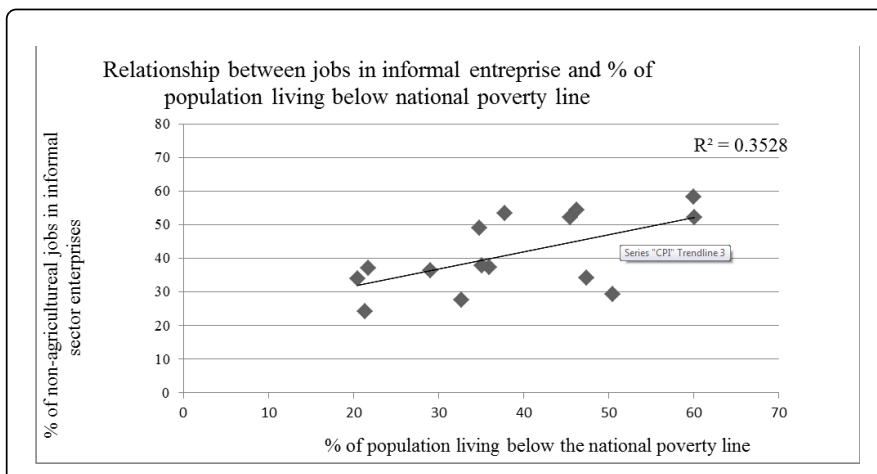

Figure 5: Relationship between jobs in informal enterprise and \% of population living below national poverty line

To graphically depict the relative importance of employment in informal sector enterprises in these Latin American economies, Figure 1 provides a spectrum along which countries can be positioned according to the share of the non-agricultural workforce with their main job in informal sector enterprises. As the final column of Table 1 reveals, none of these Latin American have all non-agricultural workers either in formal or informal enterprises, and there are no 'nearly informal' or 'nearly formal', or even 'dominantly formal' or 'dominantly informal'. Instead, 19 per cent are 'largely formal' economies, 44 per cent are 'mostly formal' economies, 6 per cent are 'semi-formal' economies and 31 per cent are 'semi-formal' economies. These Latin American countries are clustered towards the middle of the spectrum, but are skewed towards the formalized end of the spectrum.

Given these findings concerning the cross-national variations in the proportion of the non-agricultural workforce whose main job is in an informal sector enterprise, attention now turns towards evaluating critically the neo-liberal perspective that explains these cross-national 
variations and proposes a particular policy approach for tackling informal enterprise.

\section{Analysis: Evaluating the Neo-Liberal Approach}

To evaluate the neo-liberal explanation for the cross-national variations in the scale of employment in informal sector enterprises, an exploratory analysis of the validity of each of the three neo-liberal hypotheses is here undertaken.

\section{Evaluating the neo-liberal taxation hypothesis (H1)}

To evaluate the first neo-liberal hypothesis that asserts how the level of employment in informal enterprises will be greater in countries with higher tax rates, an evaluation is here undertaken of the relationship between cross-national variations in tax rates and crossnational variations in the level of employment in informal enterprises.

To do this, five different taxation measures are investigated. Commencing with the correlation between the cross-national variations in the level of employment in informal sector enterprises and the level of taxes on goods and services as a percentage of revenue, and using Spearman's rank correlation coefficient due to the nonparametric nature of the data, the finding is that there is no statistically significant relationship $(\mathrm{rs}=0.164)$. Examining the relationship between the level of employment in informal sector enterprises and the level of taxes on income, profits and capital gains as a proportion of revenue, no significant relationship is identified ( $r s=0.200)$. This is again the case when the cross-national variations in the level of taxes on revenue (excluding grants) as a share of GDP ( $r s=-0.321)$, tax revenue as a percentage of GDP ( $r s=-0.309)$ and the total tax rate ( $r s=-0.094)$ are analysed. The cross-national variations in the prevalence of employment in informal sector enterprises have no association with levels of taxation whichever of these tax measures is used. No evidence is found to support the neo-liberal taxation hypothesis that the level of employment in informal enterprises will be greater in countries with higher tax rates and that the solution for tackling the informal sector is to reduce tax rates.

\section{Evaluating the neo-liberal corruption hypothesis (H2)}

To evaluate this neo-liberal hypothesis which asserts that the level of employment in informal enterprises will be greater in countries with higher levels of public sector corruption, four different measures of such corruption are investigated.

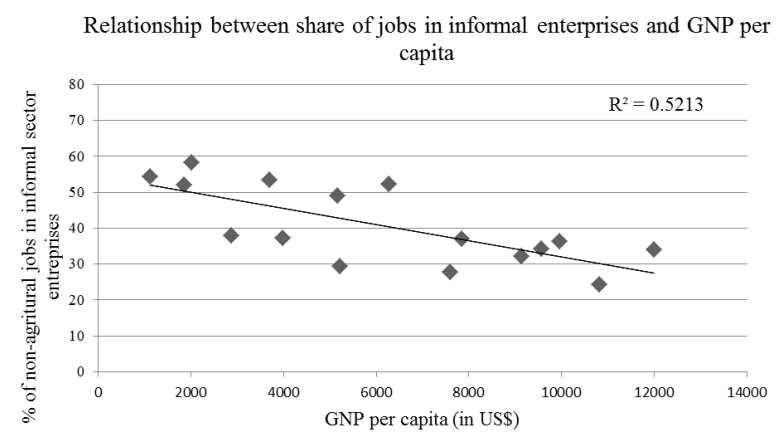

Figure 6: Relationship between share of jobs in informal enterprises and GNP per capita
Starting with Transparency International's perceptions of public sector corruption index, no significant association is identified between cross-national variations in employment in informal sector enterprises and public sector corruption ( $\mathrm{rs}=-0.380)$. Neither is any significant correlation identified between the employment in informal enterprises and cross-national variations in corruption measured by either the ICRG corruption index ( $r s=-0.066)$ or the percentage of firms who make informal payments to public officials ( $r s=-0.312$ ). However, and as Figure 2 reveals, a statistically significant association is identified at the 0.05 level between the cross-national variations in the percentage of firms who state that they are expected to give gifts in meetings with tax officials and cross-national variations in the share of the non-agricultural workforce employed in informal enterprises $\left(\mathrm{rs}=-0.599^{*}\right)$. This relationship, however, is not in the direction suggested by the neo-liberal hypothesis. It reveals that countries where a higher proportion of firms give gifts in meetings with tax officials have a lower (not higher) share of the workforce in informal sector enterprises, doubtless because it is felt by enterprises that being formal but using 'informal' bribes is a more workable solution than being wholly informal sector enterprises. There is thus no evidence to support the neo-liberal hypothesis that the level of employment in informal enterprises is greater in countries with higher levels of public sector corruption.

\section{Evaluating the neo-liberal de-regulatory hypothesis (H3)}

To evaluate the neo-liberal de-regulatory hypothesis which asserts that the level of employment in informal enterprises will be greater in countries with higher levels of state interference in the workings of the free market, six different measures of state intervention are evaluated.

Comparing the cross-national variations in the level of employment in informal enterprises and cross-national variations in the time required (in days) to start a business, which signals whether there is a burdensome regulatory environment for venture start-ups, the finding is that there is no significant correlation ( $r s=-0.088)$. Neither is there any significant correlation between cross-national variations in the share of the workforce in informal enterprises and cross-national variations in the time spent dealing with officials as a percentage of management time by enterprise owners $(r s=0.000)$. Nor is there a correlation with the World Bank's ease of doing business' ranking of countries, which is a relative proxy of the regulatory burden in countries ( $\mathrm{rs}=0.171)$.

There is however, and as Figure 3 displays, a strong statistically significant association at the 0.01 level between cross-national variations in the share of the workforce in informal sector enterprises and cross-national variations in the time required in days to obtain an operating license $\left(\mathrm{rs}=0 .-799^{* *}\right)$. However, this relationship is not in the direction suggested by neo-liberal thought. The more days that are required to obtain an operating license, the smaller (not larger) is the proportion of the workforce in informal sector enterprises, thus contradicting neo-liberal thought.

Turning to whether state intervention in social protection increases informality as neo-liberals assert, or decreases informality as political economists argue, the relationship between cross-national variations in employment in informal sector enterprises and the level of social contributions as a percentage of revenue can be analyzed. No significant association is identified $(\mathrm{rs}=-0.233)$. However, a statistically significant association at the 0.05 level is identified between crossnational variations in the share of the workforce in informal 
enterprises and the generosity of all social protection as measured by the World Bank $\left(\mathrm{rs}=-0.566^{*}\right)$. As Figure 4 reveals, the greater the coverage and generosity of social protection in a country, the smaller is the share of the workforce employed in informal enterprises. This supports the political economy explanation that greater state intervention to protect workers from poverty reduces the share of the workforce employed in informal enterprises since it provides them with an alternative means of support thus preventing them having to turn to the informal sector in the absence of alternatives.

Indeed, this political economy thesis is further supported when the cross-national variations in employment in informal sector enterprises and cross-national variations in the proportion of the population living below the national poverty line is analyzed. The finding as Figure 5 reveals is a strong statistically significant relationship at the 0.01 level $\left(\mathrm{rs}=0.546^{* *}\right)$. The greater is the share of the population living below the national poverty line, the higher is the level of employment in informal sector enterprises. This strongly suggests that employment in informal sector enterprises may well be an activity of last resort turned to by populations in the absence of alternative sources of livelihood as political economists argue, rather than a voluntarily chosen activity as neo-liberals assert.

Indeed, it is not just the tenets of the political economy thesis that find support when analyzing the cross-national variations in the share of the workforce employed in informal enterprises across these 16 Latin American countries. The conventional modernization thesis which asserts that the share of employment in informal sector enterprise is lower in 'developed' wealthier economies and greater in 'less developed' economies is also supported. As Figure 6 reveals, there is a strong significant relationship between the level of employment in informal sector enterprise in a country and its GNP per capita $\left(\mathrm{rs}=-0.765^{\star *}\right)$. The direction of this relationship is that the share of the non-agricultural workforce employed in informal sector enterprises is greater in countries with lower levels of GNP per capita.

\section{Conclusions}

Reporting the results of an ILO dataset on the level of employment in informal sector enterprises conducted in 16 Latin American economies, this paper has shown that one in three non-agricultural workers have their main job in informal sector enterprises. This brings informal sector enterprises out of the margins. Such enterprise is not a small segment of the economy in Latin American of limited importance. A significant share of the workforce has their main job in such enterprises in the informal sector. Nevertheless, marked crossnational variations exist and this paper has evaluated critically the neoliberal approach. This contends that higher proportions of the workforce are in informal sector enterprises in countries with higher taxes, corruption and state interference and that the remedy is tax reductions, tackling corruption and pursuing minimal state intervention.

Evaluating critically the validity of this neo-liberal approach in relation to Latin American countries, the finding is that cross-national variations in the level of employment of informal sector enterprises is not correlated with the level of taxation (H1) or the level of corruption (H2). Examining the relationship between the share of the workforce in informal sector enterprises and the degree of state interference in the form of social protection and burdensome bureaucracy (H3), no evidence has been found to support the neo-liberal assertion that informality is a result of too much state interference. Whichever tenet of the neo-liberal perspective is analyzed, no evidence has been found to support the notion that higher proportions of the workforce are in informal sector enterprises in countries with higher taxes, corruption and state interference, and that the remedy is tax reductions, tackling corruption and pursuing minimal state intervention.

However, even if no support has been found for the neo-liberal approach, this paper has found evidence to support the political economy perspective which conversely argues that higher proportions of the workforce are in informal sector enterprises in countries where there is less state intervention to protect workers from poverty. In Latin America, the share of the workforce in informal sector enterprises is strongly correlated with higher levels of poverty, and greater levels of social protection result in lower levels of informality, doubtless because this reduces the need for populations to turn to the informal sector as a survival tactic in the absence of alternatives. Consequently, this study of the cross-national variations in the share of the workforce employed in informal sector enterprises in Latin America not only reveals support for the political economy perspective but also the modernization perspective since it shows that informality is lower in more developed modern economies as measured by GNP per capita.

The result is that these findings have both theoretical and policy implications. In terms of the theoretical implications, they raise grave doubts about whether tax levels, corruption and state interference explain the cross-national variations in the share of the workforce employed in the informal sector. Instead, the findings provide tentative support for both the modernization explanation that views informality as a product of economic under-development and the political economy explanation that defines the problem as not one of over-regulation but rather, under-regulation of economies and a lack of state intervention to protect workers from poverty. The consequent suggestion is that to explain the cross-national variations in the share of the workforce employed in the informal sector in Latin America; there is a need to synthesize the modernization and political economy perspectives in a new 'neo-modernization' perspective. This explains lower levels of employment in informal sector enterprises as associated with economic development, smaller shares of the population in poverty and greater levels of social protection. This neomodernization thesis now requires further evaluation in terms of whether it holds both across a broader range of countries as well as when time-series data is examined for individual nations. It might also be useful to explore a wider range of economic and social conditions associated with state intervention in, and regulation of, work and welfare provision (e.g., the quality of state governance, labor market policy interventions to protect vulnerable groups, regulations on temporary employment) to further develop this neo-modernization perspective in a more nuanced manner.

This tentative rejection of the neo-liberal explanation and highlighting how higher proportions of the workforce are in informal sector enterprises when there is economic under-development, greater poverty rates and inadequate social protection also has clear implications for policy. Over the past few decades, the policy debate on tackling the informal sector has been whether targeted repressive measures and/or targeted incentives are the most effective and efficient means for moving employment in informal enterprises into the formal economy $[16,39,40,43,49,51,52]$. This paper, in stark contrast to this conventional policy literature, has uncovered that broader economic and social policy measures are important. The overarching modernization of economies, reducing poverty and social protection 
are all closely associated with the level of employment in informal enterprise. Tackling employment in informal sector enterprise seemingly requires not only a mix of targeted policy measures but also the introduction of broader economic and social policies. Whether this policy implication is confirmed when a wider range of countries are investigated, as well as when time-series data is investigated for individual countries, needs to be evaluated in future research. If more countries are analyzed furthermore, such as by using the World Bank Enterprise surveys [53], multivariate regression analysis could also be employed to evaluate the importance of each condition to the final outcome whilst controlling for other economic and social conditions. This would overcome a limitation of this paper.

In sum, through a study of 16 Latin American countries, this paper has started to question the validity of the neo-liberal advocacy of tax reductions, tackling corruption, de-regulation and minimal state intervention when tackling employment in the informal sector. To take this further forward, it will be now necessary to evaluate whether this critique of the neo-liberal approach is more widely valid. If this paper thus stimulates wider evaluation of this neo-liberal approach in other global regions, it will have fulfilled one of its intentions. If it also encourages a fuller evaluation both in Latin America and other global regions of whether more rather than less state intervention to protect workers from poverty might be the way forward in tackling employment in informal sector enterprises, it will have fulfilled all of its objectives.

\section{References}

1. Geertz C (1963) Old Societies and New States: the quest for modernity in Asia and Africa. Collier-Macmillan Publishers, New York, USA.

2. Lewis A (1959) The Theory of Economic Growth, Allen and Unwin Publishers, London.

3. Williams CC (2013) Beyond the formal economy: evaluating the level of employment in informal sector enterprises in global perspective. J Dev Entrepreneurship 18: 4 .

4. Becker KF (2004) The informal economy, Swedish International Development Agency, Stockholm.

5. De Soto H (1989) The other path, Harper and Row, London.

6. De Soto H (2001) The Mystery of Capital: why capitalism triumphs in the West and fails everywhere else, Black Swan, London.

7. London T, Hart SL (2004) Reinventing strategies for emerging markets: beyond the transnational model. J Int Bus Stud 35: 350-70.

8. Nwabuzor A (2005) Corruption and development: new initiatives in economic openness and strengthened rule of law. J Bus Ethics 59: 121-38.

9. Hussmanns R (2005) Measuring the informal economy: from employment in the informal sector to informal employment. Working Paper no. 53, ILO Bureau of Statistics, Geneva.

10. ILO (2011) Statistical update on employment in the informal economy, ILO Department of Statistics, Geneva.

11. ILO (2012) Statistical update on employment in the informal economy, ILO Department of Statistics, Geneva.

12. Boeke JH (1942) Economies and economic policy in dual societies, Tjeenk Willnik, Harlem.

13. Buehn A, Schneider F (2012) Shadow economies around the world: novel insights, accepted knowledge and new estimates. International Tax and Public Finance 19: 139-171.

14. Feld LP, Schneider F (2010) Survey on the shadow economy and undeclared earnings in OECD Countries. German Economic Review 11: 109-49.

15. Jütting JP, Laiglesia JR (2009) Employment, poverty reduction and development what's new? in Jütting JP and Laiglesia JR edn Is Informal Normal? Towards more and better jobs in developing countries, OECD, Paris 1-20.
16. OECD (2012), Reducing opportunities for tax non-compliance in the underground economy, OECD, Paris.

17. Rodgers P and Williams CC (2009) The informal economy in the former Soviet Union and in central and eastern Europe. Int J Sociol 39: 3-11.

18. Schneider F and Williams CC (2013), The Shadow Economy, Institute of Economic Affairs, London.

19. Williams CC (2014) Out of the shadows: a classification of economies by the size and character of their informal sector. Work, Employment and Society.

20. Castells M and Portes A (1989) World underneath: the origins, dynamics and effects of the informal economy. Portes A, Castells M and Benton L edn. The informal economy: studies in advanced and less developing countries, John Hopkins University Press, Baltimore, 19-41.

21. Davis M (2006) Planet of slums, Verso, London.

22. Gallin D (2001) Propositions on trade unions and informal employment in time of globalisation. Antipode 19: 531-49.

23. Sassen S (1996) Service employment regimes and the new inequality. In Mingione E edn. Urban poverty and the underclass, Basil Blackwell, Oxford 142-59.

24. Slavnic Z (2010) Political economy of informalization. European Societies 12: 3-23.

25. Taiwo O (2013) Employment choice and mobility in multi-sector labour markets: theoretical model and evidence from Ghana. Int Labor Review 152: 469-92.

26. Ahmad AN (2008) Dead men working: time and space in London's ('illegal') migrant economy. Work, Employment and Society 22: 301-18.

27. Gaetz S and O'Grady B (2002) Making money: exploring the economy of young homeless workers. Work, Employment and Society 16: 433-56.

28. Ghezzi S (2010) The fallacy of the formal and informal divide: lessons from a Postfordist regional economy. In Marcelli E, Williams CC and Joassart P edn. Informal Work in Developed Nations, Routledge, London 114-131.

29. Cross JC (2000) Street vendors, modernity and postmodernity: conflict and compromise in the global economy. Int J Sociology Soc Pol 20: 29-51.

30. Cross JC and Morales A (2007) Introduction: locating street markets in the modern/postmodern world. In Cross JC and Morales A edn. Street entrepreneurs: people, place and politics in local and global perspective, Routledge, London.

31. ILO (2002) Decent work and the informal economy, International Labor Office, Geneva.

32. Neuwirth R (2011) Stealth of Nations: the global rise of the informal economy, Pantheon Books, New York.

33. Williams CC (2004) Small Business in the Informal Economy: making the transition to the formal economy. Small Business Council, London.

34. Snyder KA (2004) Routes to the informal economy in New York's East village: crisis, economics and identity. Sociological Perspectives 47: 215-41.

35. Venkatesh SA (2006) Off the books: the underground economy of the urban poor. Harvard University Press, Cambridge, US.

36. Williams CC (2006) The hidden enterprise culture: entrepreneurship in the underground economy. Edward Elgar, Cheltenham.

37. Williams CC (2010) Spatial variations in the hidden enterprise culture: some lessons from England. Entrepreneurship and Regional Development 22: 403-23.

38. Williams CC (2011) A critical evaluation of competing representations of informal employment: some lessons from England. Rev Soc Econ 69: 211-237.

39. Williams CC and Nadin S (2012a) Tackling the hidden enterprise culture: government policies to support the formalization of informal entrepreneurship. Entrepreneurship and Regional Development 24: 895-915.

40. Williams CC and Nadin S (2012b) Tackling entrepreneurship in the informal economy: evaluating the policy options. J Entrepreneurship Public Pol 1: 111-124.

41. Williams CC and Martinez-Perez A (2014) Is the informal economy an incubator for new enterprise creation? a gender perspective. International Journal of Entrepreneurial Behaviour and Research 20: 4-19.

42. Williams CC, Rodgers P and Round J (2011) Explaining the normality of informal employment in Ukraine: a product of exit or exclusion? Am J Econ Sociol 70: 72955.

43. Dibben P and Williams CC (2012) Varieties of capitalism and employment relations: informally dominated market economies. Industrial Relations: a Rev Econ Soc 51: 563-82.

44. Sauvy A (1984) Le Travail Noir et l'Economie de Demain, Calmann-Levy, Paris. 
Citation: Williams CC, Youseff Y (2014) Tackling Informal Entrepreneurship in Latin America: A Critical Evaluation of the Neo-Liberal Policy Approach. J Entrepren Organiz Manag 3: 112. doi:10.4172/2169-026X.1000112

Page 9 of 9

45. Perry GE and Maloney WF (2007) Overview: Informality - exit and exclusion. In Perry GE, Maloney WF Arias OS, Fajnzylber P, Mason AD and Saavedra-Chanduvi J Edn. Informality: exit and exclusion, World Bank, Washington,US 1-20.

46. Lindbeck A (1981) Work Disincentives in the Welfare State, Institute for International Economic Studies, University of Stockholm, Stockholm.

47. Okun AM (1975) Equality and Efficiency: the big trade-off, Brookings Institute, Washington DC.

48. World Bank (2013a) World Development Indicators, World Bank, Washington DC, USA.

49. Williams CC, Renooy P (2013) Tackling Undeclared Work in 27 European Union Member States and Norway: approaches and measures since 2008, Eurofound, Dublin.
50. European Commission (2013) Employment and Social Developments in Europe 2013, European Commission, Brussels.

51. Feld LP and Larsen C (2012) Undeclared work, deterrence and social norms: the case of Germany, Springer Verlag, Berlin.

52. Williams CC and Lansky M (2013) Informal employment in developed and developing economies: perspectives and policy responses. Int Labour Rev 152: 355-80.

53. World Bank (2013b) Enterprise surveys, Washington, US. 